annually to the officer who is considered by the committee to have done most to promote the advancement of naval or military hygiene by professional work of outstanding merit, and is open to medical officers of the Royal Navy, the Army and the Indian Army, with the exception of the professors and assistant professors of the Royal Navy Medical College at Greenwich and the Royal Army Medical College during their term of office.

\section{Studies in Ancient Indian History and Geography}

Regulations have now been framed for the work of the Trust founded by the generosity of Dr. Bimila Churn Law, of Calcutta. The funds of the Trust will be used to facilitate the publication of original contributions to the literature on Buddhism, Jainism and the ancient history and geography of India, down to the end of the thirteenth century A.D. The Trust will be administered by the Royal Asiatic Society. Applications for assistance under the terms of the Trust for the period January 1, 1937-December 31,1938 , should be addressed to the Secretary of the Society, 74 Grosvenor Street, S.W.1.

\section{Science and Society}

THE Association of Scientific Workers has organized a series of five public lectures under the general title "Science and Society", to be given at University College, London, on successive Wednesdays, beginning February 17. The lectures cover a wide range of topics, and the whole series should prove of unusual interest to scientific workers. Prof. J. B. S. Haldane will talk on "Facts and Theories concerning Human Race Differences" on February 17, and the chairman on this occasion will be Sir F. Gowland Hopkins. On the following Wednesdays, the lecturers will be A. L. Bacharach on "Nutrition and Society", Prof. H. Levy on "The Socialization of Mathematics", Prof. P. M. S. Blackett, on "Physics" and Prof. Lancelot Hogben on "The Social Background of Science". This is the first of an annual series of lectures on the general implications of science which the Association hopes to arrange. Further information and tickets (1s. for each lecture, 4s. for course of five) can be obtained from the Assistant Secretary, Association of Scientific Workers, Kelvin House, 28 Hogarth Road, S.W.5.

\section{Checking the Michelson-Morley Experiment}

THe following cablegram has been received from Prof. W. B. Cartmel, of the University of Montreal : " 'A Simple Means of Checking the Michelson-Morley Experiment'. In a letter under the above title which appeared in NATURE of January 16, I reported experiments in which I found a large fringe-shift with a small interferometer having one arm inclined at an angle of $45^{\circ}$ and the other arm level. Unfortunately, on continuing my experiments with improved apparatus, this fringe-shift disappeared altogether, so that we get the same result with one arm inclined and one arm level as we do with both arms level, the effect previously reported being apparently spurious."

\section{Announcements}

H.R.H. THE DUKe of Gloucester has accepted the invitation to become president of the British Empire Cancer Campaign. His Majesty the King, when Duke of York, was president of the Campaign from 1924 until his accession to the throne.

The Council of the Physical Society has awarded the fourteenth Duddell Medal to Prof. W. G. Cady, of the Wesleyan University, Middletown, Connecticut, U.S.A.

Mr. Colin Bevan Rees has been awarded the Foyle Prize at the University College of South Wales for his essay on "Can Science make a Positive Contribution to the Elimination of Armed Conflict ?"

Dr. Lours Vervaeck, director of the service of criminal anthropology in Belgium, has been awarded the Cesare Lombroso prize for criminal anthropology.

McGill University, Montreal, has recently received a gift of 17,000 dollars from the Rockefeller Foundation to cover the expenses of a three-year programme of research in genetics and experimental cytology.

Applications for grants from the Ella Sachs Plotz Foundation for 1937-38 must be made before May 1 . For the present, researches will be favoured that are directed towards the solution of problems in medicine and surgery or in branches of science bearing on medicine and surgery. Further information can be obtained from Dr. Joseph C. Aub, Collis P. Huntington Memorial Hospital, 695 Huntington Avenue, Boston, Massachusetts, U.S.A.

The Trustees of the Lady Tata Memorial Fund invite applications for grants and scholarships for research in diseases of the blood, with special reference to leukæmia, in the academic year beginning on October 1, 1937. The grants and scholarships are open to workers of any nationality. Applications must be submitted before March 31 , and the awards will be made by the Trustees in June. Further particulars and forms of application may be obtained from the Secretary of the Scientific Advisory Com: mittce, 138 Bedford Court Mansions, London, W.C.1.

Attention may be directed to catalogue No. 42 of Messrs. E. P. Goldschmidt and Co., 45 Old Bond Street, W.1, on navigation, geography, travels and shipbuilding. The catalogue, which is illustrated with several reproductions of old maps, contains many old and rare items including Amman's "Die grosse Allegorie auf den Handel", 1622 ; Belleforest's "Cosmographie Universelle", 1575; Honter's "Rudimenta cosmographica", 1542, of which very few copies are known; a hitherto unknown first map of Japan, 1586 ; and Kepler's "Tabulae Rudolphinae", 162730 , containing his rare world map, which Nordenskjöld believed to be the earliest map showing any indication of the Australian coast line. 